\title{
Tree ferns dominate secondary succession in abandoned pineapple plantations around Manu National Park, Peru
}

\author{
Olivia Schilling ${ }^{1}$ and Adrian Tejedor ${ }^{2}$
}

${ }^{1}$ The Evergreen State College. ${ }^{2}$ The School for Field Studies

\section{Correspondencia}

A.Tejedor

e-mail: adriantejedor@gmail.com

Recibido: 24 junio 2017

Aceptado: 16 septiembre 2017

Publicado on-line: diciembre 2017

\begin{abstract}
Habitat management and restoration in buffer zones of national parks is critical for maintaining ecosystem services and biological connectivity in and around the parks' core protected areas. Vegetation succession in abandoned plantations in buffer zones may take different paths that reach climax ecosystems in more or less time depending on the conditions of initial succession, thus enhancing or hindering biological connectivity and ecosystem services. This study documents the dominance of tree ferns in the initial stages of vegetation succession on abandoned pineapple plantations on the Andean foothills around Manu National Park, Peru, and discusses the role it may have on ecosystem restoration. Four years after abandonment, tree fern gametophytes grow under the shade of pineapple plants and melastomes. After 6-10 years of succession, the vegetation is dominated by a tree fern community composed of at least eight species, of which the most common are by far Cyathea delgadii and Cyathea microdonta. Cyathea microdonta functions as a short-lived pioneer, reaching its peak of live stem density in 6 to10 years and dying off in older plots. Cyathea delgadii, on the other hand, continues to grow and persists beyond 10 years of succession. Areas adjacent to abandoned pineapple fields have few tree ferns and higher tree species diversity, suggesting that pineapple agriculture and the resulting tree fern community may be a longer pathway to reach climax vegetation stages than other types of plantation.
\end{abstract}

Key words: vegetation succession, tree ferns, Peru, Amazon, Manu National Park

\section{Resumen}

Los helechos arborescentes dominan la sucesión secundaria en plantaciones de piña abandonadas alrededor del Parque Nacional del Manu, Perú

El manejo y la restauración de hábitats en áreas de amortiguamiento de parques nacionales son críticos para mantener los servicios ecosistémicos y la conectividad biológica alrededor de las zonas núcleo de las áreas protegidas. La sucesión ecológica en plantaciones abandonadas en áreas de amortiguamiento pueden seguir cursos diferentes que alcanzan estabilidad en más o menos tiempo en dependencia de las condiciones iniciales de la sucesión, mejorando u obstaculizando los servicios ecosistémicos y la conectividad biológica. Este estudio documenta la dominancia de los helechos arborescentes en las etapas iniciales de la sucesión ecológica en piñales abandonados en el piedemonte Amazónico de los Andes en el Parque Nacional del Manu. Cuatro años después del abandono de las plantaciones, los gametofitos de helechos arborescentes se encuentran creciendo a la sombra de plantas de piña y de la familia Melastomataceae. Después de 6-10 años de sucesión, la vegetación aparece dominada por una comunidad de helechos arborescentes de al menos ocho especies, entre las cuales las más comunes son Cyathea delgadii y Cyathea microdonta. Cyathea microdonta funciona como una especie pionera de vida corta, alcanzando su pico de densidad a los 6-10 años y prácticamente desapareciendo en parcelas más antiguas. Cyathea delgadii, 
por otro lado, continua creciendo y persiste más allá de los diez años. Las áreas adyacentes a los piñales abandonados muestran relativamente pocos helechos arborescentes y mayor diversidad de árboles, lo cual sugiere que el cultivo de piña y la comunidad de helechos arborescentes que le sucede puede ser un mecanismo de sucesión más largo hacia la recuperación de la vegetación clímax que otros tipos de cultivos.

Palabras clave: sucesión ecológica, helechos arborescentes, Perú, Amazonia, Parque Nacional del Manu

\section{Introduction}

Under advancing degradation and fragmentation of the world habitats, conservation strategies will increasingly rely on active management and ecosystem restoration to ensure biological connectivity and maintenance of ecosystem services (Lindenmayer, 2008, Suding, 2011). Together with remnant patches of original habitats, restored habitats will likely be major components of biological corridors (Chazdon, 2008), and their management must include an understanding of pathways and mechanisms of ecological succession (Young et al., 2001). Buffer areas of national parks and other protected areas, are habitat restoration hotspots due to the higher degradation pressures they sustain (SanchezAzofeifa et al., 2003), and because, in the tropics, they mostly consist of highly dynamic rotational agriculture landscapes with the potential to revert to climax habitats (Chapman, 1999).

Manu National Park, in the Peruvian AmazonAndes region, is the core protected area of Manu Biosphere Reserve, a UNESCO Natural World Heritage Site due to the high biological diversity encompassed in its 300-4020 $\mathrm{m}$ elevation gradient (Yallico and Suarez de Freitas, 1995). It is surrounded by a buffer zone that includes two different land uses. Along the northern and western boundaries, it is flanked by legally protected natural and indigenous reserves, mostly devoid of commercial large-scale land use change (Yallico and Suarez de Freitas, 1995). Along the eastern and southern boundaries, on the other hand, it is flanked by a more populous, $9 \mathrm{~km}$ wide Cultural Zone that is not legally protected but where sustainable economic activities are allowed, including low impact extraction of timber and other forest products, agriculture, ecotourism, and subsistence hunting (Shepard et al., 2010). As in much of Amazonian Peru, in the tropical belt of Manu's Cultural Zone, with the exception of coca cultivation, agriculture has remained almost entirely rotational (Bishop, 1982), allowing secondary forests to regenerate on abandoned crops for several years.

Beginning in the 1980s, private ecological reserves have sprung up in Manu's Cultural Zone (Yallico and Suarez de Freitas, 1995), some of which have inherited considerable degrees of habitat disturbance from previous timber extraction, cattle grazing, and rotational agriculture. Established in 2010, Villa Carmen Biological Station and Reserve is one of such private reserves, which, in addition to old growth forests, supports land continuously used for timber and rotational agriculture since the early $20^{\text {th }}$ century ( $G$. Muñiz, pers. comm.). Fallow plots that had been used for different crops in Villa Carmen, appear to support markedly different successional assemblages, among which nearly pure stands of tree ferns growing on abandoned pineapple fields at different stages of succession are particularly striking. This study aimed to investigate the composition and dynamics of the tree fern community established on abandoned pineapple at Villa Carmen Biological Station in order to document the vegetation succession on one of the most common crops around Manu National Park, and understand its role in forest regeneration and potential reversal to climax habitat in the buffer zone of this biosphere reserve.

\section{Objectives}

To document the composition and dynamics of tree fern successional communities on abandoned pineapple plantations in the buffer zone of Manu National Park and understand the role of these communities in the regeneration of climax forest.

\section{Methods}

Our study was conducted in November 2013 and February 2014 on the Villa Carmen Biological Station and Reserve $\left(12^{\circ} 53^{\prime \prime} \mathrm{N}, 71^{\circ} 24, \mathrm{~W}\right.$, $)$, 
managed by the Amazon Conservation Association (ACA). The station is located near Pilcopata in the Kosñipata Valley, Cusco, Peru at an elevation of $520 \mathrm{~m}$. The reserve protects premontane rainforest adjacent to Manu National Park, which shows increasing degrees of disturbance closer to the station. The average annual precipitation is 3000$5000 \mathrm{~mm}$ and the average annual temperature is $23^{\circ} \mathrm{C}$.

Three plots were set up in each of four stages $(4,6,10$ and 12 years old) of abandoned pineapple fields. Plots were $10 \times 10 \mathrm{~m}$, where adult tree ferns were counted and measured, and each contained 25 subplots of $1 \times 1 \mathrm{~m}$ each, randomly placed were gametophytes and young sporophytes were counted. All ferns were identified to species and very young sporophytes that could not be identified were counted separately. Subplots were accessed by $30 \mathrm{~cm}$ wide paths cut in one direction every two meters as well as around the borders. Trees and tree ferns were left undisturbed if within the $30 \mathrm{~cm}$ paths and pineapple plants were trimmed but not removed. Tree fern trunk height was measured in the individuals that could be identified to species from the ground to the tip of the trunk apex. Dead ferns were also measured, counted and identified. Mean heights and densities between ages and species were compared with ANOVA tests. All statistical analyses were conducted using JMP Pro 10 (JMP Statistics, SAS, Inc., Cary, NC).

Figure 1. Changes in structure of a tree fern community in Pilcopata, Cusco, Peru, across 12 years of secondary succession. A). Decrease in density of earlier demographic classes, gametophytes and young sporophytes not identified to species (ANOVA, $p<0.05$ ). $B)$. Mean increase in height of the two dominant species in the community, C. delgadii and C. microdonta (ANOVA, $\mathrm{p}<0.05)$. C). Density of adult sporophytes across 8 years of succession. Cyathea microdonta decreases in density and almost disappears by year 12 (ANOVA, $p<0.05$ ), whereas the density of $C y$ athea delgadii remains virtually unchanged (ANOVA, p>0.05). Figura 1. Cambios en la estructura de una comunidad de helechos arborescentes en Pilcopata, Cusco, Perú, a lo largo de 12 años de sucesión secundaria. A). Disminución en la densidad de las clases etarias más jóvenes, gametofitos y esporofitos jóvenes no identificables (ANOVA, p<0.05). B). Incremento en promedio de la altura de las dos especies dominantes en la comunidad, $\mathrm{C}$. delgadii $y \mathrm{C}$. microdonta (ANOVA, p<0.05). C). Densidad de esporofitos adultos a lo largo de 8 años de sucesión. Cyathea microdonta disminuye en densidad y prácticamente desaparece al doceavo anho (ANOVA, $p<0.05$ ), mientras que la densidad de $\mathrm{C}$. delgadii no cambia significativamente (ANOVA, $p>0.05$ ).
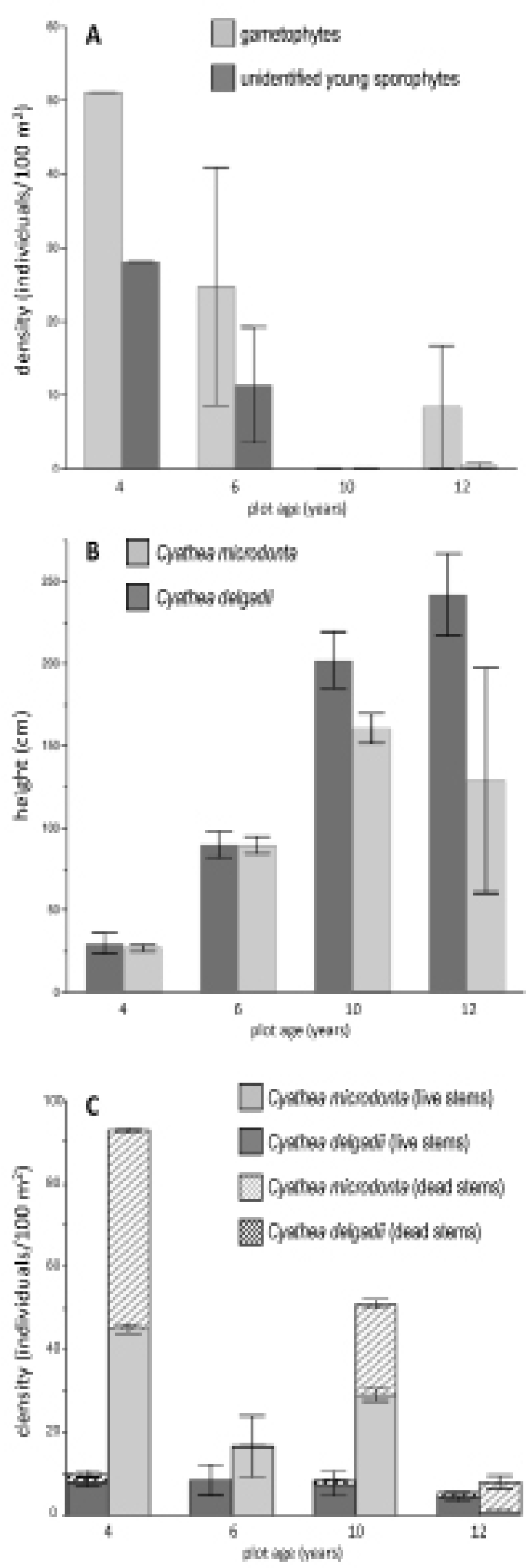


\section{Results}

Eight species of tree ferns were found growing in 12 abandoned pineapple plots at Villa Carmen Biological Station: Cyathea microdonta (Desv.) Domin (258 individuals), Cyathea delgadii Sternb. (93), Cyathea leucolepismata Alston (5), Cyathea pungens (Willd.) Domin (3), Cyathea subincisa (Kunze) Domin (2), Alsophila cuspidata (Kunze) D.S. Conant (1), Cyathea dombeyi (Desv.) Lellinger (1), Cyathea lasiosora (Mett. ex Kuhn) Domin (1). After abandonment, tree fern establishment took place underneath the pineapple plants and a $60 \mathrm{~cm}$ tall cover of Melastomataceae. By the fourth year of abandonment, bare soil around pineapple plants was covered with a sparse carpet of gametophytes averaging 51 individuals $/ \mathrm{m}^{2}$, unidentified young sporophytes averaging 29 individuals $/ \mathrm{m}^{2}$, and a $25 \mathrm{~cm}$ tall layer of older sporophytes that could be identified to species, which averaged 5.3 individuals $/ \mathrm{m}^{2}$ (fig. 1, 2). Succession after four years was marked by a decrease in the number of gametophytes, a thinning of young and adult sporophytes, and growth of adult sporophytes at an average rate of $22.5 \mathrm{~cm} /$ year (fig $1, \mathrm{p}<0.05$ ).

The two most common tree ferns, $C$. microdonta and $C$. delgadii differed markedly in their life history. Cyathea microdonta functioned as short-lived pioneer species, with an initial highly dense population (45 individuals $/ 100 \mathrm{~m}^{2}$ ) that accounted for $85 \%$ of all young sporophytes that could be identified to species. The number of live young sporophytes of $C$. microdonta was matched by a similar number (48 individuals $/ 100 \mathrm{~m}^{2}$ ) of dead individuals, indicating a high juvenile mortality. After 6 years, it decreased on average in stem density and almost died off completely at 12 years of forest regrowth. Its trend of decreasing density, however, was broken by the production of 3-5 lateral trunks after the death of the main trunk (fig 2). Lateral trunks continued to grow until the eventual death of the entire plant in the 12 year old plot but never attained the height of 10 year old solitary trunks. Cyathea delgadii, on the other hand, did not change in stem density between 4 and 12 years of secondary succession and its solitary trunks grew linearly at an average rate of $23.75 \mathrm{~cm} / y e a r(f i g ~ 1$, $p>0.05$ ). Its juvenile mortality in the 4 year old plot was only $4 \%$ that of $C$. microdonta.

\section{Discussion}

The results presented here indicate that pineapple cultivation and subsequent abandonment at the Amazonian foothills of the Andes sets off a peculiar kind of vegetation succession involving a rich tree fern community with two densely represented, dominant species, $C$. microdonta and $C$. delgadii. The density of tree ferns in the abandoned pineapple fields at Villa Carmen is the highest reported from the Neotropics (Table 1), being 19 times higher than the average density found in neighboring secondary forest of the reserve (A. Min, unpublished data) and 1.5-42 times higher than densities found in lowland to premontane forests elsewhere in the New World (Table 1). Other sites with high tree fern densities, albeit still lagging far behind the abandoned pineapple fields at Villa Carmen, are at much higher elevations (La Planada, Colombia with 16

Figure 2. Five stages of tree fern dominated succession in Pilcopata, Cusco, Peru, across 12 years. A) Tree fern gametophytes (dark green kidney-shaped structures). Note young seedling of Melastomataceae at center top. B) young tree fern sporophyte of an unidentified species. C) young sporophyte identified to species, in this case, Cyathea microdonta. All young tree fern age classes were growing under the shade of $60 \mathrm{~cm}$ tall shrubby Melastomataceae and pineapple plants. D) six year old tree fern stand amid Brachiaria sp. and other grasses. Note isolated incipient pioneer angiosperm trees (Cecropia sp., Trema sp., and Jacaranda copaia). Shrubby Melastomataceae are still present in small numbers. E). ten year old plot overtaken by 1-2.5 $\mathrm{m}$ tall Cyathea delgadii (labelled $\mathrm{Cd}$ in photo) and Cyathea microdonta (all other trunks). Pioneer trees (Cecropia sp. and Jacaranda copaia) have increased in height and Melastomataceae are absent. Pineapple plants, the original crop, persist in the understory, now under the shade of the tree ferns. Figura 2. Cinco estadios de sucesión dominada por helechos arborescentes en Pilcopata, Cusco, Perú, a lo largo de doce años. A) Gametofitos de helechos arborescentes (estructuras arriñonadas de color verde oscuro). Nótese la plántula de Melastomataceae en el centro superior. B) esporofito joven de helechos arborescente de especie no identificada. C) esporofito joven identificable, en este caso, C. microdonta. Todos los estadios jóvenes de helechos arborescentes en la sucesión estudiada crecían bajo la sombra de Melastomataceae arbustivas de $60 \mathrm{~cm}$ de altura y de plantas de piña. D) Helechos arborescentes en la sucesión de seis años entre Brachiaria sp., otros pastos, y angiospermas arborescentes pioneras (Cecropia sp., Trema sp., $y$ Jacaranda copaia). Las melastomatáceas arbustivas aún están presentes en pequeño número. E) sucesión de 10 años dominada por C. delgadii (Cd en la foto) y C. microdonta (todos los demás troncos) de 1-2.5 m de altura. Arboles pioneros (Cecropia sp. y Jacaranda copaia) tienen un mayor tamaño en este estadio y las melastomatáceas han desaparecido. Plantas de piña, el cultivo original, persisten en el sotobosque, ahora bajo la sombra de los helechos arborescentes. 


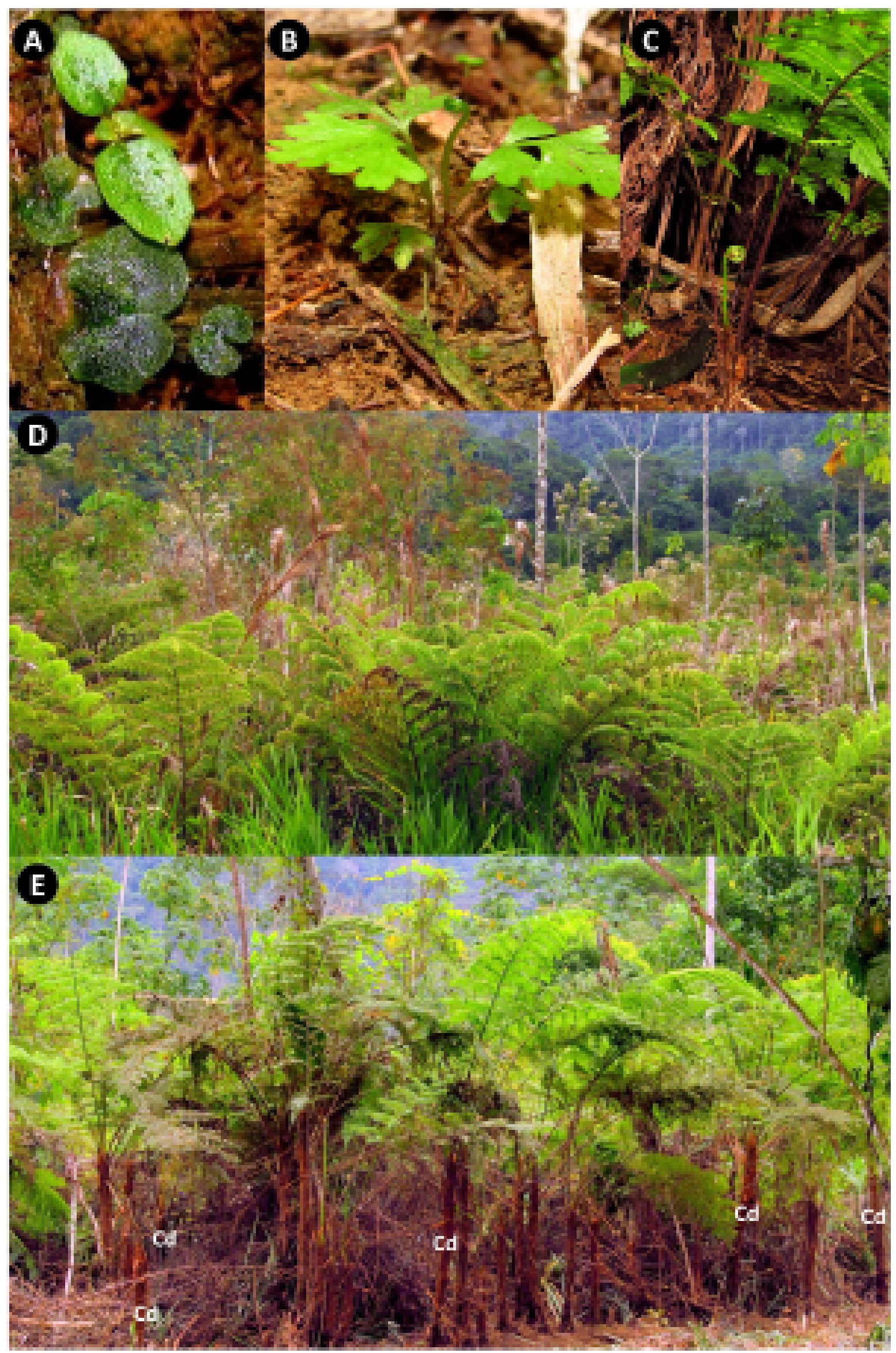




\begin{tabular}{|c|c|c|c|c|c|}
\hline LOCALITY & $\begin{array}{l}\text { REGION, } \\
\text { COUNTRY }\end{array}$ & $\begin{array}{l}\text { APPROXIMATE } \\
\text { ELEVATION (m) }\end{array}$ & TAXA SAMPLEDa & $\begin{array}{c}\text { DENSITY } \\
\text { (adults } / 100 \mathrm{~m}^{2} \text { ) }\end{array}$ & SOURCE \\
\hline Villa Carmen - pineapple & CUS, Per & 500 & all tree ferns ${ }^{b}$ & 38.0 & this study \\
\hline Villa Carmen - forest & CUS, Per & 500 & all tree ferns & 2.0 & A. Min, unpublished data \\
\hline Quitacalzon - stream forest & CUS, Per & 1000 & all tree ferns & 28.3 & A. Min, unpublished data \\
\hline La Planada & NAR, Col & 2000 & all tree ferns & 16.0 & Arens and Baracaldo, 1998 \\
\hline Una & BA, Bra & 30 & all tree ferns & 0.9 & Paciencia and Prado, 2005 \\
\hline Sapiranga & RS, Bra & 570 & Alsophila setosa & 23.5 & Schmitt and Windisch, 2005 \\
\hline Morro Reuter & RS, Bra & 700 & Alsophila setosa & 17.4 & Schmitt and Windisch, 2005 \\
\hline Novo Hamburgo & RS, Bra & 20 & Cyathea delgadii & 2.1 & Schmitt and Windisch, 2007 \\
\hline Vale do Ribera - old growth & SP, Bra & 500 & all tree ferns & 1.8 & Castello et al., 2017 \\
\hline Vale do Ribera - secondary & SP, Bra & 500 & all tree ferns & 1.3 & Castello et al., 2017 \\
\hline Cuyabeno & NA, Ecu & 250 & all tree ferns ${ }^{c}$ & 3.2 & Poulsen and Nielsen, 1995 \\
\hline San Francisco Biol. Sta. & ZC, Ecu & 2000 & two species ${ }^{d}$ & 7.9 & Chacón-Labella et al., 2015 \\
\hline La Selva & LIM, CR & 60 & four species & 2.1 & Jones et al., 2007 \\
\hline
\end{tabular}

Table 1. Average density of tree ferns found after ten years of succession in abandoned pineapple plantations in Pilcopata, Cusco, Peru, compared to tree fern densities in lowland and middle elevation forests elsewhere in the Neotropics. In the Manu region, abandoned pineapple plantations support the highest tree fern densities found thus far in the New World. ${ }^{a}$ Not all densities correspond to the entire tree fern community or samples were only a subset of the potential local diversity. ${ }^{b} \mathrm{C}$. delgadii and $C$. microdonta. ${ }^{\mathrm{C}} \mathrm{C}$. lasiosora. ${ }^{\mathrm{d}}$ Alsophila engelii and $C$. squamipes/C. lindeniana (treated as $C$. caracasana). Tabla 1. Densidad promedio de helechos arborescentes después de diez años de sucesión en plantaciones abandonadas de piña en Pilcopata, Cusco, Perú, comparada con densidades de helechos arborescentes de tierras ajas y elevaciones medias en otras localidades Neotropicales. Las plantaciones de piña abandonadas en la región del Manu muestran las mayores densidades de helechos arborescentes reportadas hasta la fecha en el Neotrópico. ${ }^{a}$ No todas las densidades corresponden a la comunidad de helechos arborescentes en su totalidad o la muestra es solo una parte de la diversidad potencial local. ${ }^{b} \mathrm{C}$. delgadii and C. microdonta. ${ }^{\circ} \mathrm{C}$. lasiosora. ${ }^{d}$ Alsophila engelii and C. squamipes/C. lindeniana (treated as C. caracasana).

adults $/ 100 \mathrm{~m}^{2}$ in at $2000 \mathrm{~m}$, Arens and Baracaldo, 1998), occur in wetter microenvironments such as ravines (Quitacalzon, Peru with 28.3 adults/100 $\mathrm{m}^{2}$, A. Min unpublished data), or involve species that produce multiple trunks (Alsophila setosa Kaulf, Schmitt and Windisch, 2005). No doubt the fact that $C$. microdonta produces multiple trunks, between the sixth and tenth years of succession, contributes to the exceptionally high densities of tree ferns dominating abandoned pineapple fields around Manu National Park.

The difference in life history traits observed for the two dominant tree ferns, wherein $C$. microdonta gets established at high densities and tends to die off after approximately 12 years of forest regrowth whereas $C$. delgadii changes little if anything in density and continues growing under forest shade confirms previous observations about the ecology of these species. Cyathea microdonta is commonly found in cleared areas and swampy terrain (Large and Braggins, 2007) and seems to form part of the natural beach succession along large piedmont rivers (pers. observ.). Cyathea delgadii, on the other hand, even though it thrives in disturbed sites such as landslides and road cuts, tends to occur more often inside the forest (M. Lehnert, pers. comm.).

The fivefold decrease in the abundance of gametophytes in the 12 year old plots relative to the four year old plots, however, indicate that tree fern recruitment in the older plots should be lower than in younger ones. Therefore, over longer succession periods than those sampled here, even Cyathea delgadii might decrease in density from the average of 7.5 individuals $/ 100 \mathrm{~m}^{2}$ reported here to numbers closer to the background densities (1-2 individuals $/ 100 \mathrm{~m}^{2}$ ) found in most Neotropical moist lowland forests.

The tree fern dominated succession on abandoned pineapple differs sharply in species composition from neighboring succession mosaics of the same age but on different crops such as pasture and banana. At the study site, abandoned pasture (Brachiaria sp.) tends to develop into a nearly monotypic secondary forest of bamboo 
(Guadua sarcocarpa Londoño \& P.M. Peterson) and abandoned banana plantations tend to develop into a mixed species secondary forest dominated by Cecropia spp., Pourouma tomentosa Mart. ex Miq., Triplaris americana L., Acacia sp., Jacaranda copaia (Aubl.) D. Don), Socratea exhorriza (Mart.) H. Wendl., and Guarea guidonia (L.) Sleumer (pers. observ.). Both the bamboo stands and the mixed-species associations are more similar to the composition of older-growth forest in the area (Huamantupa-Chuquimaco, 2010). In the tree fern succession, pineapple plants persist on the forest floor for over 12 years whereas in other abandoned crops the crop species disappear within 3-4 years (pers. observ.). All this suggests that abandoned pineapple and its succeeding tree fern community is a longer than optimal pathway to the regeneration of climax forest.

A possible reason for the unusual high density of tree ferns in abandoned pineapple fields around Manu may be the soil amendment techniques used in the region. Local farmers frequently apply ammonium sulfate $\left(\left(\mathrm{NH}_{4}\right)_{2} \mathrm{SO}_{4}\right)$ as fertilizer to pineapple fields but rarely to other crops (Y. Espinosa, pers. comm.). As shown in studies of bean (Thomson et al., 1993), corn (Blevins et al. 1977), peach (Tagliavini et al., 1995), and natural temperate ecosystems (Van Miegroet and Cole, 1984) nitrogen fertilizers decrease soil $\mathrm{pH}$. Acidic substrates ( $\mathrm{pH} 4-5)$, in turn, have been shown to favor spore germination and the development of gametophytes in several tree fern species (Marcon et al., 2017, Medeiros et al., 2017, Rechenmacher et al. 2010). It is possible then that soil acidification following the fertilization of pineapple fields in the Manu region allow tree ferns to recruit more competitively than pioneer arborescent angiosperms such as Cecropia and Jacaranda. The observation that pineapple grown without nitrogen soil amendments become invaded by grasses rather than tree ferns (Y. Espinosa, pers. comm.) and the dominance of Melastomataceae in younger plots (4 year old) both support the soil acidity hypothesis. Melastomataceae richness and abundance have been found to be strongly correlated with low cation content in the soil (Tuomisto et al. 2002) which is in turn usually correlated with lower $\mathrm{pH}$ (Van Miegroet and Cole, 1984).

\section{Conclusions}

This study documents an unusual ecological succession pathway in the Amazonian foothills of the Andes, through which tree ferns, instead of angiosperm trees, take over abandoned pineapple plantations for the first 10 years of secondary succession. Tree fern communities in abandoned pineapple plantations are up to 42 times denser than those in other abandoned crops or mature forests in the Neotropical lowlands. Two species, Cyathea microdonta and Cyathea delgadii dominate these tree fern communities. Of the two, the more common $C$. microdonta behaves like a short-lived pioneer, starting out with a density ten times that of $C$. delgadii but largely disappearing from the vegetation after 12 years of succession. Cyathea delgadii, on the other hand, persists with almost no mortality and continues growing at a linear rate at least until 12 years of succession and probably beyond. The tree fern dominated succession appears to slow down the establishment of a rich angiosperm pioneer community and it seems to be triggered by soil acidification through nitrogen fertilization. This suggests that habitat management in buffer zones of protected areas in the Andes/Amazon region aimed to restore climax forest should avoid soil amendment with nitrogen fertilizers. Further studies involving soil $\mathrm{pH}$ manipulation are clearly necessary to confirm this recommendation.

\section{Acknowledgements}

We thank the Amazon Conservation Association (ACA) for hosting us and for logistical support. Kathy Ruttenberg generously funded part of the fieldwork. Villa Carmen field staff Adrian Quispe and Julio Manutupa kindly help with plot establishment. Annika Min graciously provided unpublished density estimates from Villa Carmen's older secondary forests. We are grateful to Shaughn Dugan and Andrew Wilcox for assistance in the field and especially to Yngrid Espinosa for help with data collection, for useful insights, and for safeguarding abandoned pineapple plantations at different stages of succession. The School for Field Studies (SFS) supported AT in the later stage of the study.

\section{References}

Arens, N. C., \& Baracaldo, P. S. (1998). Distribution of tree ferns (Cyatheaceae) across a successional mosaic in an Andean cloud forest, Nariño, Colombia. American Fern Journal, 88, 60-71.

Bishop, J.P. (1982). Agroforestry systems for the humid tropics cast of the Andes. In S. B. Hecht. (Ed.). Amazonia: agriculture and land use research. (pp. 428). Cali/Colombia: CIAT.

Blevins, R. L., Tomas, G. W., \& Cornelius, P. L. (1977). Influence of No-tillage and Nitrogen Fertilization on Certain Soil Properties after 5 Years of Continuous Corn. Agronomy Journal, 69(3), 383-386. doi:10.2134/ agronj1977.00021962006900030013x

Castello, C. D., Coelho, S., \& Cardoso-Leite, E. (2016). Lianas, tree ferns and understory species: indicators of conservation status in the Brazilian Atlantic Rainforest 
remnants, southeastern Brazil. Brazilian Journal of Biology. http://dx.doi.org/10.1590/1519-6984.07715

Chacón-Labella, J., De la Cruz, M., Vicuña, R., Tapia, K., \& Escudero, A. (2014). Negative density dependence and environmental heterogeneity effects on tree ferns across succession in a tropical montane forest. Perspectives in Plant Ecology, Evolution and Systematics, 16, 52-63.

Chapman, C.A. \& Chapman, J. L. (1999). Forest restoration in abandoned agricultural land: A case study from East Africa. Conservation Biology, 13,1301-1311.

Chazdon, R. L. (2008). Beyond deforestation: restoring forests and ecosystem services on degraded lands. Science, 320,1458-1460

Jones, M. M.1, Olivas Rojas, P., Tuomisto, H., \& Clark, D. (2007). Environmental and neighbourhood effects on tree fern distributions in a neotropical lowland rain forest. Journal of Vegetation Science,18,13-24.

Large, M. F. \& Braggins, J. E. (2004). Tree Ferns. Portland, Cambridge: Timber Press.

Marcon, C., Silveira, T., Schmitt, J. L. \& Droste, A. (2017). Abiotic environmental conditions for germination and development of gametophytes of Cyathea phalerata Mart. (Cyatheaceae. Acta Botanica Brasilica, 31(1), 58-67. doi: 10.1590/0102-33062016abb0288.

Medeiros, L. G., Marcon, C., Silveira, T., Schmitt, J. L., \& Droste, A. (2017). Looking for the conservation and sustainable use of Cyathea corcovadensis (Raddi) Domin (Cyatheaceae): the influence of environmental factors on gametophytes. Brazilian Journal of Botany, 40(1),13-20.

Paciencia, M. L. B., \& Prado, J. (2005). Distribuição espacial da assembleia de pteridofitas em uma paisagem fragmentada de Mata Atlântica no sul da Bahía, Brasil. Hoehnea 32(1),103-117. https://www. researchgate.net/publication/263734042

Poulsen, A. D., \& Nielsen, I. H . (1995). How Many Ferns Are There in One Hectare of Tropical Rain Forest? American Fern Journal, 85(1), 29-35.

Rechenmacher, C., Schmitt, J. L., \& Droste, A. (2010). Spore germination and gametophyte development of Cyathea atrovirens (Langsd. \& Fisch.) Domin (Cyatheaceae) under different $\mathrm{pH}$ conditions, Brazilian Journal of Biology, 70(4), 1155-1160

Sanchez-Azofeifa, G. A., Daily, G. C., Pfaff, A. S. P., \& Busch, C. (2003). Integrity and isolation of Costa Rica's national parks and biological reserves: examining the dynamics of land-cover change. Biological Conservation, 109,123-35. http://oregonstate.edu/ instruct/bot440/wilsomar/Content/HTM-trees.htm
Schmitt, J. L., \& Windisch, P. D. (2005). Aspectos ecológicos de Alsophila setosa Kaulf. (Cyatheaceae, Pteridophyta) no Rio Grande do Sul, Brasil. Acta Botanica Brasilica, 19(4), 859-865. http://www.scielo. $\mathrm{br} / \mathrm{pdf} / \mathrm{abb} / \mathrm{v} 19 \mathrm{n} 4 / \mathrm{a} 21 \mathrm{v} 19 \mathrm{n} 4 . \mathrm{pdf}$

Schmitt, J. L., \& Windisch, P. D. (2007). Estrutura populacional e desenvolvimento da fase esporofítica de Cyathea delgadii Sternb. (Cyatheaceae, Monilophyta) no sul do Brasil. Acta Botanica Brasilica, 21(3), 731-740. http://www.scielo.br/pdf/abb/v21n3/ a19v21n3

Shepard, G. H., Jr., Rummenhoeller, K., Ohl-Schacherer, J., \& Yu, D. W. (2010). Trouble in Paradise: Indigenous Populations, Anthropological Policies, and Biodiversity Conservation in Manu National Park, Peru. Journal of Sustainable Forestry, 29(2), 252-301, DOI: 10.1080/10549810903548153

Suding, K. N. (2011). Toward an Era of Restoration in Ecology: Successes, Failures, and Opportunities Ahead. Annual Review of Ecology, Evolution, and Systematics, 42, 465-87

Tagliavini M., Masia, A., \& Quartieri, M. (1995). Bulk soil $\mathrm{pH}$ and rhizosphere $\mathrm{pH}$ of peach trees in calcareous and alkaline soils as affected by the form of nitrogen fertilizers. Plant and Soil,176( 2), 263-271.

Thomson, C. J., Marschner, H., \& Römheld, V. (1993). Effect of nitrogen fertilizer form on $\mathrm{pH}$ of the bulk soil and rhizosphere, and on the growth, phosphorus, and micronutrient uptake of bean. Journal of Plant Nutrition. 16(3), 493-506.

Tuomisto, H., Ruokolainen, K., Poulsen, A. D., Moran, R. C., Quintana, C., Canas, G. \& Celi, J. (2002). Distribution and diversity of pteridophytes and Melastomataceae along edaphic gradients in Yasuni National Park, Ecuadorian Amazonia. Biotropica 34, 516-533.

Van Miegroet, H. \& Cole, D. W. (1984). The impact of nitrification on soil acidification and cation leaching in a red alder ecosystem. Journal of Environmental Quality 13, 586-590.

Young, T.P., Chase, J.M. \& Huddleston, R.T. (2001). Community succession and assembly - comparing, contrasting and combining paradigms in the context of ecological restoration. Ecological Restoration, 19, 5-18.

Yallico, L., \& Suarez de Freitas, G. (1995). The Manu Biosphere Reserve, Peru. UNESCO, South-South Cooperation Programme on Environmentally Sound Socio-Economic Development in the Humid Tropics, Working Papers. 8, 1-47. http://unesdoc.unesco.org/ images/0011/001139/113933eo.pdf 